Luciana Pinto de Andrade

\title{
Governança Corporativa dos Bancos no Brasil
}

\author{
DissertaÇÃo de MESTRAdo
}

Departamento de AdMINISTRAÇÃo Programa de Pós-Graduação em Administração de Empresas 


\title{
Luciana Pinto de Andrade
}

\section{Governança Corporativa dos Bancos no Brasil}

\author{
Dissertação de Mestrado
}

Dissertação apresentada como requisito parcial para obtenção do grau de Mestre pelo Programa de PósGraduação em Administração de Empresas do Departamento de Administração da PUC-Rio.

Orientador: Marcelo Cabús Klotzle 


\section{Luciana Pinto de Andrade}

\section{Governança Corporativa dos Bancos no Brasil}

Dissertação apresentada como requisito parcial para obtenção do grau de Mestre pelo Programa de PósGraduação em Administração do Departamento de Administração do Centro de Ciências Sociais da PUC-Rio. Aprovada pela Comissão Examinadora abaixo assinada.

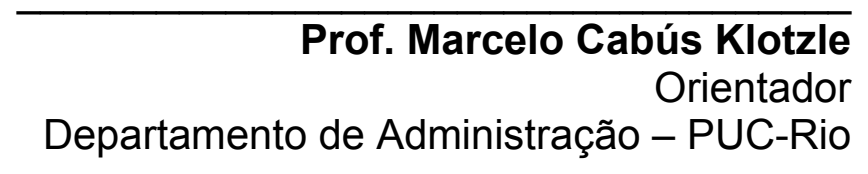

Prof. Walter Lee Ness, Jr. Departamento de Administração - PUC-Rio

Prof. Celso Funcia Lemme
COPPEAD - UFRJ

Prof. João Pontes Nogueira

Vice-Decano de Pós-Graduação do CCS

Rio de Janeiro, 7 de junho de 2005 
Todos os direitos reservados. É proibida a reprodução total ou parcial do trabalho sem autorização da universidade, da autora e do orientador.

\section{Luciana Pinto de Andrade}

Graduou-se em Economia pela Universidade Federal do Rio Grande do Sul (UFRGS) em 2002. Interesse acadêmico na área de assimetria informacional e de governança corporativa.

Ficha Catalográfica

Andrade, Luciana Pinto de

Governança corporativa dos bancos no Brasil / Luciana Pinto de Andrade ; orientador: Marcelo Cabús Klotzle. - Rio de Janeiro : PUC-Rio, Departamento de Administração, 2005.

$61 \mathrm{f} . ; 30 \mathrm{~cm}$

Dissertação (mestrado) - Pontifícia Universidade Católica do Rio de Janeiro, Departamento de Departamento de Administração.

Inclui referências bibliográficas

1. Administração - Teses. 2. Governança corporativa. 3. Bancos. I. Klotzle, Marcelo Cabús. II. Pontifícia Universidade Católica do Rio de Janeiro. Departamento de Departamento de Administração. III. Título. 


\section{Agradecimentos}

Ao meu orientador Professor Marcelo Cabús Klotzle pelo apoio, dedicação e estímulo durante a elaboração desta dissertação.

Ao meu marido Cristiano por seu amor e companheirismo incondicionais.

Aos meus pais e a minha irmã, que mesmo longe sempre me deram o amor e suporte necessários.

Às minhas amigas e colegas Renata, Mariana e Luciana.

Aos professores integrantes da Comissão Examinadora.

A todos professores do IAG pelos valiosos ensinamentos. 


\section{Resumo}

De Andrade, Luciana Pinto; Klotzle Marcelo Cabús. Governança Corporativa dos Bancos no Brasil. Rio de Janeiro, 2005. 61p. Dissertação de Mestrado Departamento de Administração, Pontifícia Universidade Católica do Rio de Janeiro.

Para minimizar a perda de valor da empresa decorrente da separação entre controle e propriedade, surgiu o conceito de governança corporativa, há cerca de vinte anos. A governança traduz-se em mecanismos internos (Conselho de Administração, Estrutura de Propriedade, Sistema de Remuneração dos Executivos, etc) e externos (mercado de fusões e aquisições e sistema legal/regulatório). A adoção de suas práticas é um processo recente no Brasil. Em virtude disto, ainda não existe uma literatura empírica consolidada sobre o assunto no país. Sendo assim, o propósito deste trabalho é investigar a influência de mecanismos internos de governança corporativa - relativos ao Conselho de Administração e à Estrutura de Propriedade - sobre o desempenho econômicofinanceiro e o valor dos bancos no Brasil. Para isso, a amostra selecionada contém 19 bancos, analisados durante o período de 1998 até 2003. Os resultados demonstram que ainda é tímida a influência dos mecanismos de governança tanto sobre a variável de desempenho analisada quanto sobre a medida de valor estudada. No entanto, estudos sugerem que pelo fato de o setor financeiro ser regulado é possível que se encontre resultados distintos daqueles preditos pela teoria e que, até então, foram obtidos para empresas não-financeiras.

\section{Palavras-chave}

Governança Corporativa; Bancos; Desempenho 


\section{Abstract}

De Andrade, Luciana Pinto; Klotzle Marcelo Cabús (Advisor). Corporate Governance in Brazilian Banks. Rio de Janeiro, 2005. 61p. MSc. Dissertation Departamento de Administração, Pontifícia Universidade Católica do Rio de Janeiro.

Over twenty years ago, the concept of corporate governance appeared to minimize the loss in the firm value due to the conflict of interest inherent in the separation between ownership by shareholders and control. Governance can be classified in two sets of mechanisms: internal (Board of Directors, Ownership Structure, Executive Compensation, etc.) and external mechanisms (Mergers and Acquisitions Market, Legal/Regulatory System, etc.). The adoption of these practices is a recent trend in Brazil. For this reason, there is no consolidated empiric literature in Brazil. In such a case, the purpose of this study is to investigate the influence of internal mechanisms of corporate governance especially the Board of Directors and the Structure of Ownership - on the performance and the firm-value of banks in Brazil. For that, the selected sample contains 19 Brazilian banks, analyzed during the period from 1998 to 2003. The results demonstrate that the influence of internal and external mechanisms on the performance variable analyzed as well as on the measure of firm value studied is still small. However, studies suggest that because financial system is a regulated sector it is possible to obtain results different from those predicted by the theory and that, until now, were obtained in studies of non-financial firms.

\section{Keywords}

Corporate Governance; Banks; Performance 


\section{Sumário}

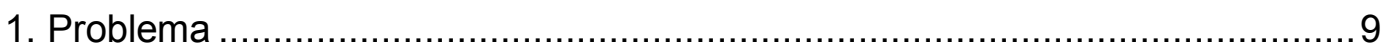

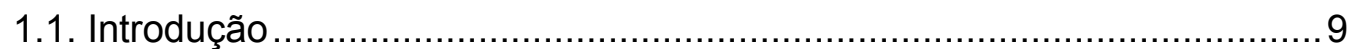

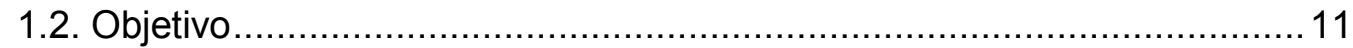

1.3. Relevância da Pesquisa .................................................................... 12

1.4. Delimitação do Estudo ................................................................. 13

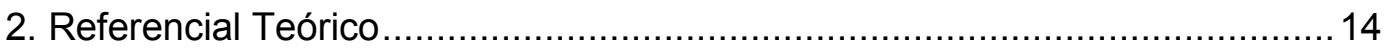

2.1. Evolução do Conceito de Governança Corporativa ................................ 14

2.2. Sistemas de Governança Corporativa .................................................. 16

2.3. Evidências Empíricas da Governança Corporativa nas Empresas Não-

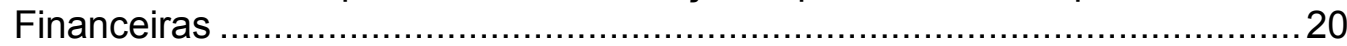

2.4. Evidências Empíricas da Governança Corporativa em Bancos ...............27

3. A Governança Corporativa no Brasil ......................................................... 30

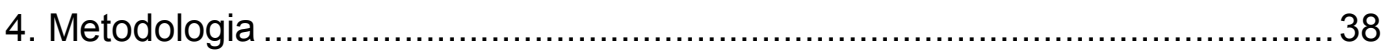

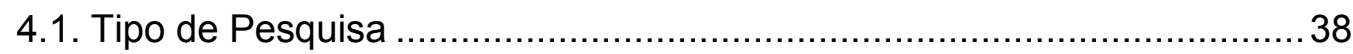

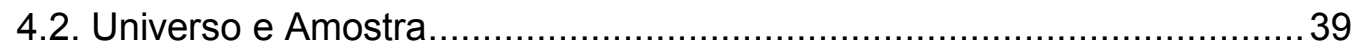

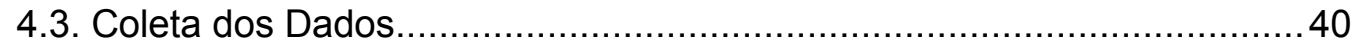

4.4. Modelo Econométrico e Tratamento dos Dados......................................41

4.5. Limitações do Método .................................................................... 44

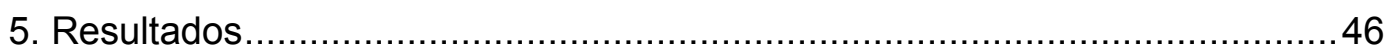

5.1. Estatísticas Descritivas e Matriz de Correlação.....................................46

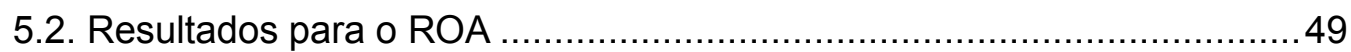

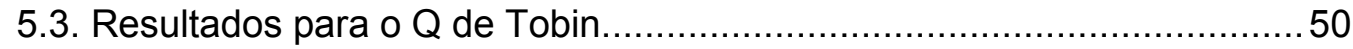

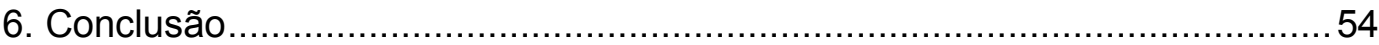

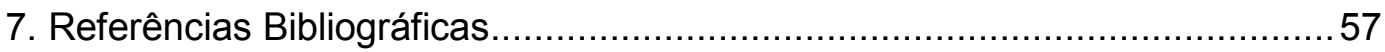

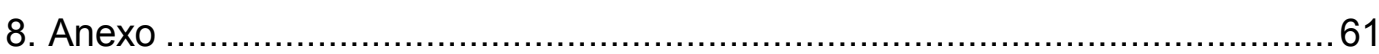




\section{Lista de Quadros}

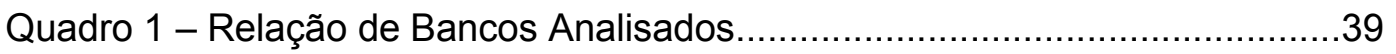

Quadro 2 - Variáveis Independentes do Estudo............................................42

Quadro 3 - Variáveis de Controle do Estudo................................................43

Quadro 4 - Estatísticas Descritivas.........................................................46

Quadro 5 - Matriz de Correlação entre Variáveis Independentes e de Controle 48

Quadro 6 - Resultado do Modelo para a Variável Dependente ROA..................49

Quadro 7 - Resultado do Modelo para a Variável Dependente Q de Tobin........51

Quadro 8 - Resultado da Simulação do Modelo para a Variável Dependente

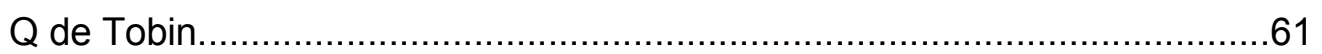

